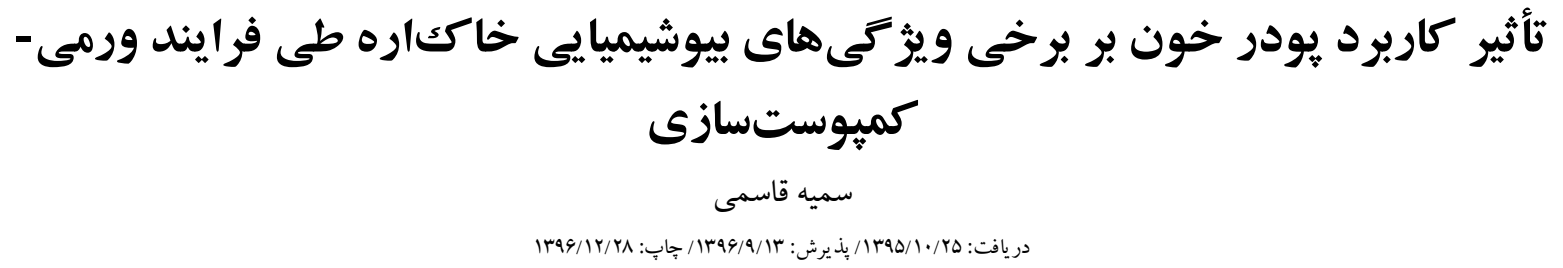

$$
\begin{aligned}
& \text { كروه علوم خاكك، دانشكدة منابع طبيعى و كشاورزى، دانشگاه يزد، يزد، ايران } \\
& \text { s.ghasemi@yazd.ac.ir :مسئول مكاتبات }
\end{aligned}
$$

جكيده. اين مطالعه با هدف بازيافت خاككاره و يودر خون با استفاده از كرم خاكى Eisenia foetida و بررسى روند تغييرات برخى ويزّى هاى بيوشيميايى اين

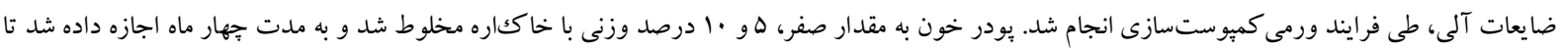

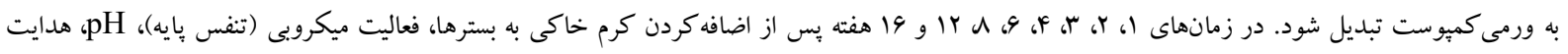

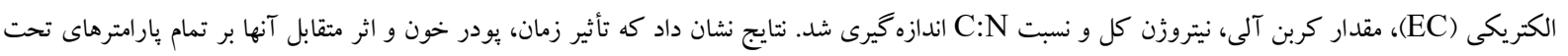

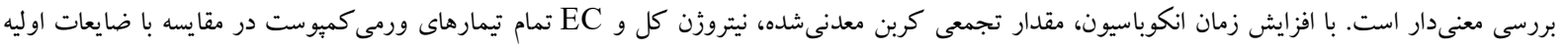

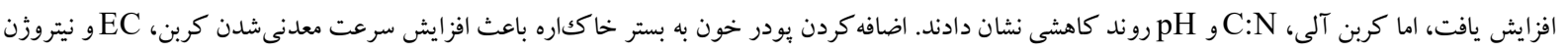

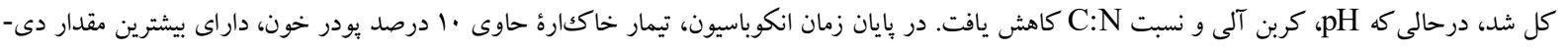

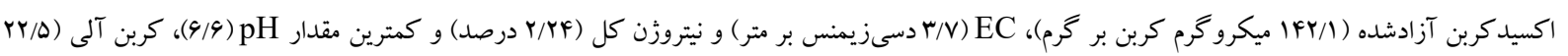

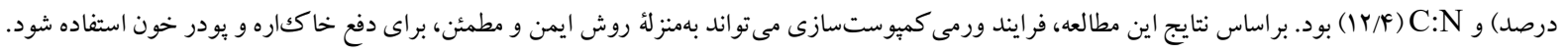

$$
\text { وازههاى كليدى. تجزيه بيوشيميايى، سرعت تجزيه، ضايعات آلى، كرم خاكى، نسبت كربن به نيتروزن }
$$

\title{
The effect of blood powder application on some biochemical properties of sawdust during vermicomposting
}

Somayeh Ghasemi

Received 14.01.2017/ Accepted 04.12.2017/ Published 19.03.2018

Department of Soil Science, Faculty of Natural Resources and Agriculture, Yazd University, Yazd, Iran *Correspondent author: s.ghasemi@yazd.ac.ir

\begin{abstract}
This study aimed to recycle sawdust and blood powder using Eisenia foetida earthworm and investigate some biochemical changes of these waste materials during vermicomposting. Blood powder was mixed with sawdust in proportions of 0,5 and $10 \%$ and the mixture was allowed to pass through earthworm guts for four months. At intervals of $1,2,3,4,6,8,12$ and 16 weeks, the biological activity (i.e. basal respiration), $\mathrm{pH}, \mathrm{EC}$, total organic carbon, total nitrogen and $\mathrm{C}: \mathrm{N}$ ratio were determined. The results showed that the period of time, the concentration of blood powder and the interaction between these two significantly affected all parameters. As the incubation time increases, the cumulative amount of mineralized carbon, the total nitrogen and EC increase in all vermicompost treatments whereas organic carbon, $\mathrm{C}: \mathrm{N}$ ratio and $\mathrm{pH}$ decreased. Adding blood powder to sawdust bed resulted in an increase in carbon mineralization rate, $\mathrm{EC}$ and total nitrogen while $\mathrm{pH}$, organic carbon and $\mathrm{C}: \mathrm{N}$ ratio decreased. At the end of incubation time, the treatment of sawdust with $10 \%$ blood powder resulted in the highest amount of released $\mathrm{CO}_{2}\left(142.1 \mu \mathrm{g} \mathrm{C} \mathrm{g}^{-1}\right)$, $\mathrm{EC}\left(3.7 \mathrm{dS} \mathrm{m}^{-1}\right)$ and total nitrogen $(2.24 \%)$ and the lowest amount of $\mathrm{pH}(6.6)$, organic carbon $(22.5 \%)$ and $\mathrm{C}: \mathrm{N}$ ratio (12.4). According to the results, the process of vermicomposting can be used as a safe method for the disposal of sawdust and blood powder.
\end{abstract}

Keywords. analysis speed, biochemical analyses, C:N ratio, earthworm, organic waste 
تجزيه كنند، اما گونه مقدمه

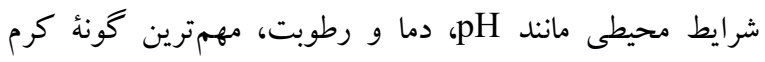
خاكى است كه در فرايند ورمى كميوستسازى ضايعات آلى به كار مىرود ) Surg et al., 2006; Suthar, 2007; Suthar, 2009; Kumar et al., 2013

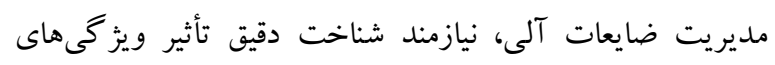

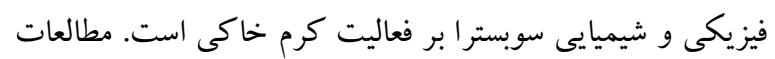

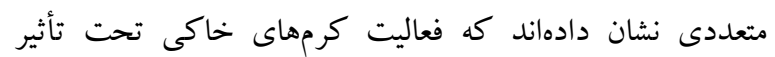

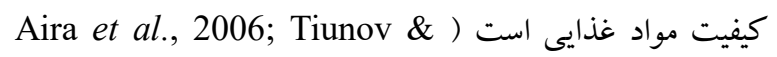

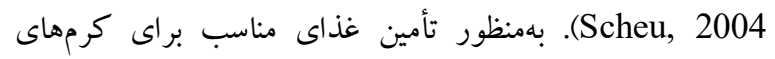

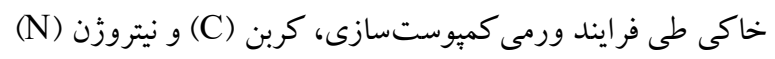

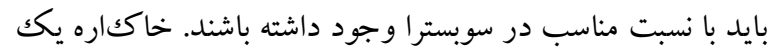

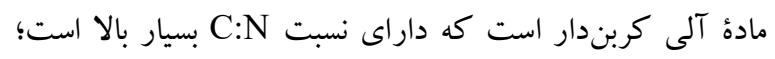

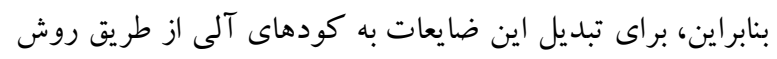

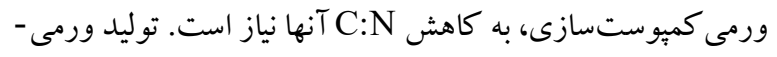

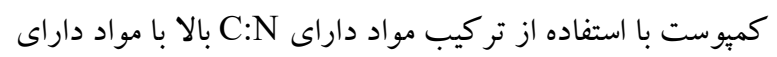
كم، بهمنظور تهيئ سوبسترا با نسبت C:N

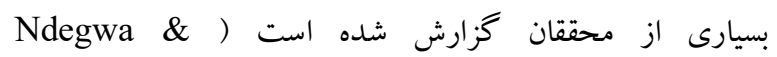
Kumar . Thompson, 2000; Suthar, 2009 (2013) دراين راستا مشاهده كردند كه تر كيب لجن فاضلاب با

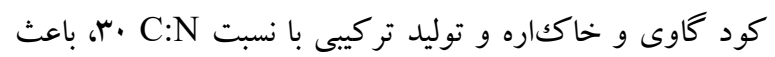

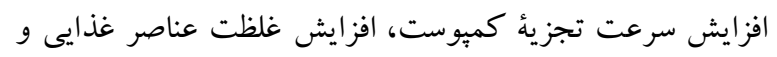

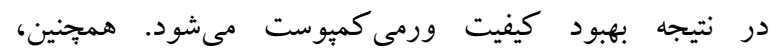
Shrimal

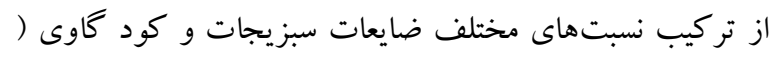

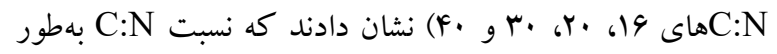
معنى

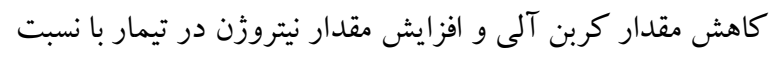
C:N در اين مطالعه فرض شد كه افزودن بودر خون، بلمنزله منبع غنى

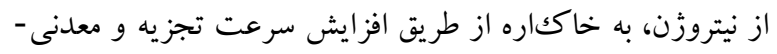

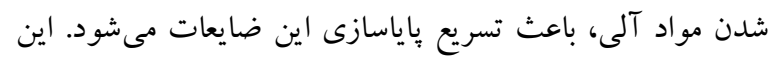

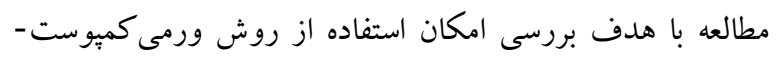

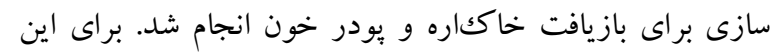

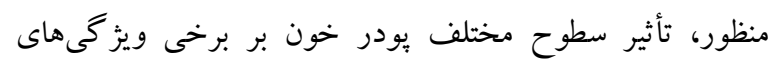

سالانه تقريباً بيش از · م ميليون تن ضايعات آلى در سرتاسر

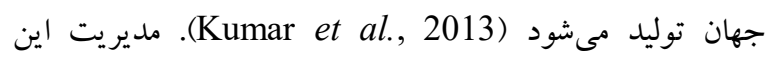

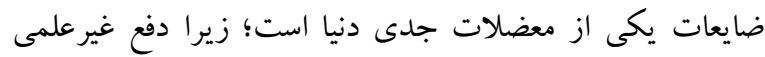

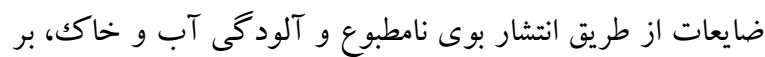

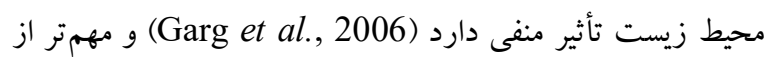

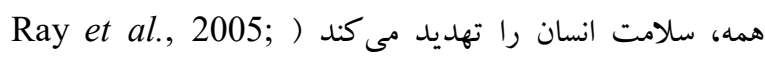
Sharholy et al., 2008 محصولات فرعى غير قابل استفاده در كار كاههاى جوب بوبرى است. توليد ضايعات جوب در اين كار گاهها اجتنابنايذير است؛

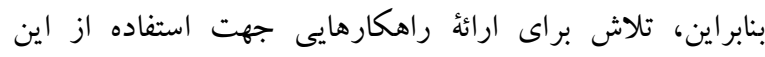
ضايعات اهميت بسيار زيادى دارد (Zziwa et al., 2006).

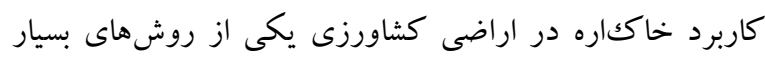

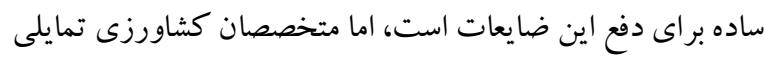

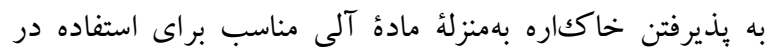
اراضى كشاورزى درنقش مالج يا اصلاح كنده خاكك ندارند؛ زيرا استفاده از خاككاره در اراضى كشاورزى مشكلاتى به همراه خواهد داشت. سرعت كم تجزية خاككاره و كاهش موقتى غلظت

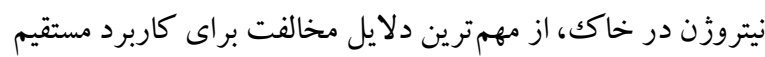

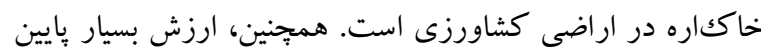

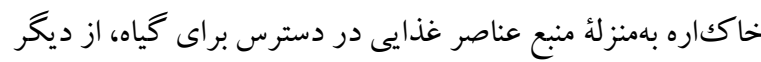

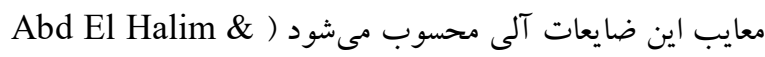
.El Baroudy, 2014 يكى از بهترين روشهاى فراورى ضايعات آلى، بازيافت آنها

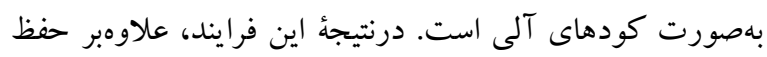
سلامت انسان و كاهش مشكلات زيستمحيطى، مقادير زيادى

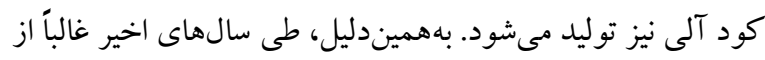

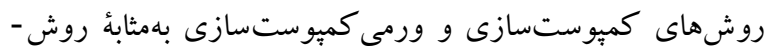

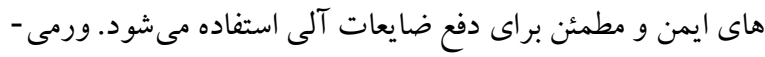

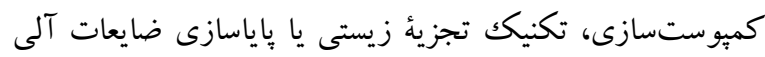

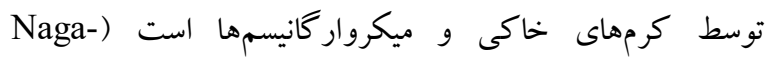
(vallemma et al., 2006; Kumar et al., 2013

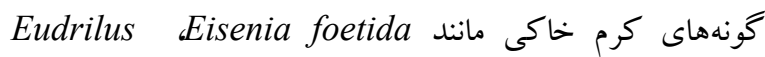
Lumbricus rubellus gerionyx excavates ،engeniae قادرند دامنه وسيعى از منابع مختلف ضايعات آلى را مصرف و 
اسيد مصرفى براى خنثى كردن سود اضافى، مقدار دىاكسيدكربن توليدشده توسط هر تيمار اندازهگيرى شد (Alexander, 1999). با اندازه گيرى تنفس ميكروبى در زمانهاى مقرر، مقادير تجمعى كربن معدنى در اين زمانها محاسبه شد. قابليت هدايت الكتريكى

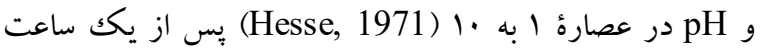
تكان دادن، درصد كربن آلى بهروش اكسيداسيون تر در مجاورت

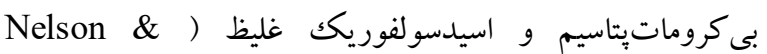
(Sommers, 1986 و درصد نيتروزن كل نيز با استفاده از دستگاه Bremmer \& ( اتو كلتك مدل . . ب براساس روش كلدال (Mulvancey, 1982

تجزية آمارى دادهها اين آزمايش در قالب طرح كاملاً تصادفى در ب تكرار انجام كرفت. تحليل آمارى دادهها با استفاده از نرمافزار SAS و مقايسٔ ميانگينها براساس آزمون LSD انجام شد و نمودارها در نرمافزار

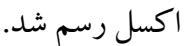

\section{نتايج و بحث}

نتايج حاصل از تجزية آمارى دادهها نشان داد كه تأثير زمان و يودر خون بر تمام بارامترهاى تحت بررسى در سطح / / درصد معنىدار است (جدول Y). اثر متقابل زمان و يودر خون بر فعاليت ميكروبى، EC ،pH، نيتروزن كل و نسبت C:N در سطح / / درصد و بر كربن آلى نيز در سطح ا درصد معنىدار بود. فعاليت ميكروبى

روند زمانى معدنىشدن كربن در تيمارهاى تحت مطالعه نشان مىدهد كه بيشترين سرعت معدنىشدن كربن آلى طى هفتهاى اول تا جهارم انكوباسيون اتفاق افتاده است و يس از آن، مقدار تجمعى كربن معدنى شده از خاككارهُ تيمارشده با بودر خون، با

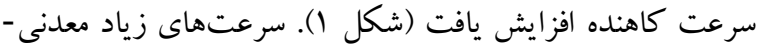
شدن كربن آلى با زمان طى روزهاى اول انكوباسيون مربوط به اجزاى محلول كربن آلى است، كه بهمرور زمان، حذف مواد محلول و افزايش نسبى تركيبات مقاوم مانند سلولز، همىسلولز و ليكنين باعث كاهش سرعت معدنى شدن كربن در مراحل بعدى Sall et al., 2007; Kosheleva \& ) تجزيه مىشود (Trofimov, 2008 نتايج نشان داد كه كاربرد يودر خون باعث افزايش معدنىشدن كربن آلى خاككاره شد، بهطورى كه مقدار
يوشيميايى خاكاره طى فرايند ورمى كمبوستسازى تحت بروسى قرار كرفت.

\section{مواد و روشها} تهية ورمى كميوست

خاككارّ ه استفادهشه در اين مطالعه از نجارىهاى شهر يزد تهيه شد. بودر خون نيز از كشتاركاه صنعتى فساران، واقع در كيلومترى شمال اصفهان تهيه شد. در اين كشتار كاه، خون حاصل از كشتار دامها، تحت دما و فشار زياد به يودر خون تبديل شد. نمونهاى يودر خون، قبل از آزمايشهاى در دماى عا درجه سلسيوس نخهدارى شدند. برخى ويز گیىهاى شيميايى خاككاره و يودر خون مورد استفاده در اين آزمايش در جدول آمده است. در اين مطالعه، يودر خون به مقدار صفر، هو · لادرصد وزنى با خاككاره مخلوط شد و بهمنظور تجزية نسبى، بهمدت جهار هفته

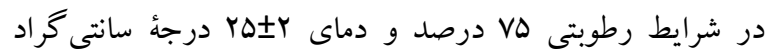

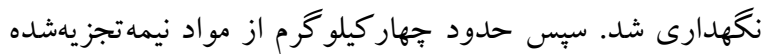
به سبدهاى يلاستيكى انتقال يافت و تعداد •ه عدد كرم جوان و بالغ (داراى حلقه جنسى) گونه E. foetida بهازاى هر كيلو گرم سوبسترا، به بسترها تزريق شد. تمام بسترها به مدت جهار ماه در

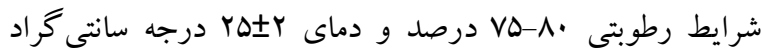
نخهدارى شدند.

تجزية بيوشيميايى

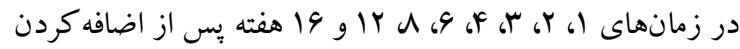
كرم خاكى به بسترها، ..1 گرم مواد از هريكك از بسترها برداشته شد و براى تعيين فعاليت ميكروبى (تنفس گِايه)، pH، هدايت الكتريكى و مقدار كربن آلى و نيتروزن كل تحت تجزئ قرار كرفت. بهمنظور اندازهيرى فعاليت ميكروبى، مقدار مشخصى از مواد بسترها در ظروف شيشهاى . . ميلىليترى ريخته شد و در هر ظرف، يكك لوله حاوى · ا ميلىليتر سود ا نرمال جهت جمع آورى كاز دىاكسيدكربن قرار داده شد. ظروف مذكور FF ساعت در

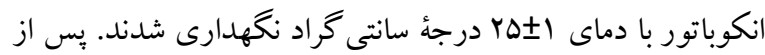
آن، محتويات لولههاى آزمايش در ارلنهاى ·له ميلىليترى ريخته شد و • إميلىليتر كلرورباريم •ا درصد براى رسوبدادن كربناتهاى توليدشده اضافه شد. سبس، توسط اسيدسولفوريك هاr/ • نرمال در حضور معرف فنولفتالئن تيتر شد و از روى ميزان 


$$
\text { جدول ا-برخى ويزگى هاى شيميايى خاككاره و يودر خون مورد استفاده در اين آزمايش. }
$$

Table 1. Some chemical properties of sawdust and blood powder used in this study.

\begin{tabular}{|c|c|c|}
\hline يودر خون & خاك اره & ويزگى \\
\hline $9 / 4$ & $V / 9$ & $\mathrm{pH}(1: 10)$ \\
\hline $9 / r$ & $1 / 1$ & هدايت الكتريكى (dS m-1) \\
\hline $\mathrm{kr} / \mathrm{V}$ & $\Delta r / F$ & كربن آلى (\%) \\
\hline $\mid r / 1$ & $\cdot / \mu$ & نيتروزن كل (٪) \\
\hline$r / r$ & $I V Y / r$ & نسبت كربن به نيتروزن \\
\hline $1 \cdot / 0$ & - & يُروتئئن خام (درصد) \\
\hline
\end{tabular}

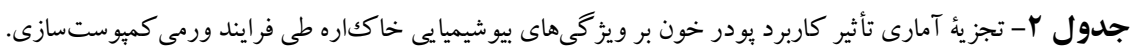

Table 2. Analysis of variance for the effect of blood powder application on the biochemical properties of sawdust during vermicomposting.

\begin{tabular}{|c|c|c|c|c|c|c|c|}
\hline $\mathrm{C}: \mathrm{N}$ & نيتروزن كل (N) & كربن آلى (C) & هدايت الكتريكى & $\mathrm{pH}$ & فعاليت ميكروبى & آزادى & منابع تغييرات \\
\hline$\mu F \mid r / \Lambda^{* * *}$ & $\cdot / 4 \Lambda^{* * *}$ & $r \Delta I N^{* * *}$ & $1 / \kappa r^{* * *}$ & $\cdot / \Delta r^{* * * *}$ & $9919 / N^{* * *}$ & $\wedge$ & زمان \\
\hline 1. rFW/Q*** & $\mid r / \Lambda^{* * *}$ & $V 90 / \Delta^{* * *}$ & $\mid r / f^{* * *}$ & $\Upsilon / \cdot V^{* * *}$ & $|\Lambda| \mid F / /^{* * * *}$ & r & يودر خون \\
\hline$v \Delta \cdot r^{* * *}$ & $1.9^{* * *}$ & $\mid r / \Lambda^{* *}$ & $\cdot \pi r^{* * *}$ & $.1 .9^{* * *}$ & $r \Delta \Delta / 9^{* * *}$ & 19 & زمان × يودرخون \\
\hline $1 r \cdot \Lambda$ &.$/ .1$ & $\Delta / 4$ & $\cdot 1 \cdot 1$ & $\cdot / \cdot r$ & $r \Delta / \Lambda$ & $\Delta F$ & خطاى آزمايش \\
\hline
\end{tabular}

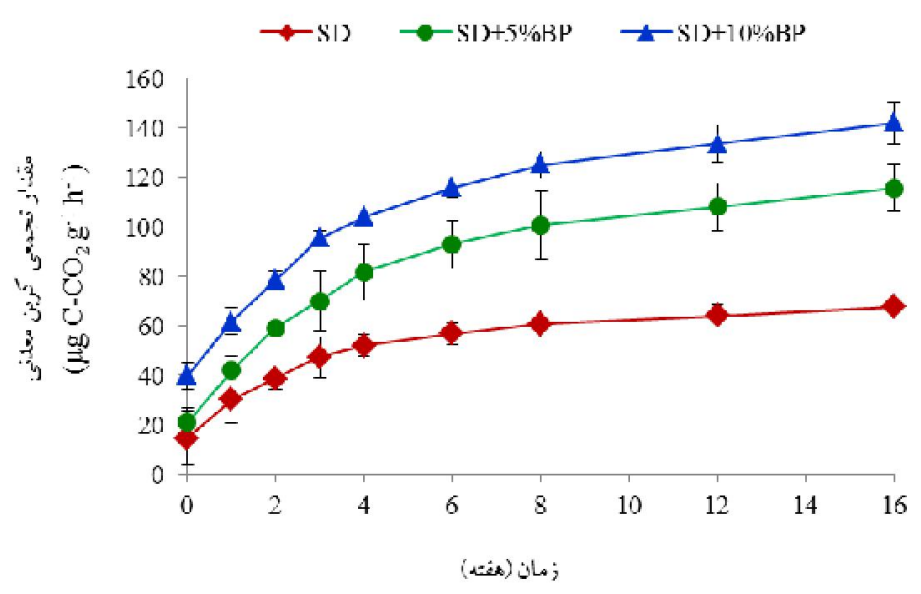

شكل ا- روند زمانى معدنى شدن كربن آلى در خاككارة (SD) تيمارشده با سطوح مختلف يودر خون (BP) طى فرايند ورمى كميوست سازى.

Fig. 1. Mineralization kinetic of organic carbon in the sawdust (SD) treated with different levels of blood powder (BP) during vermicomposting process.

كربن بر گرم در تيمار خاككاره حاوى •ا درصد يودر خون متغير

كل دىاكسيد كربن متصاعدشده طى جهار ماه انكوباسيون از و

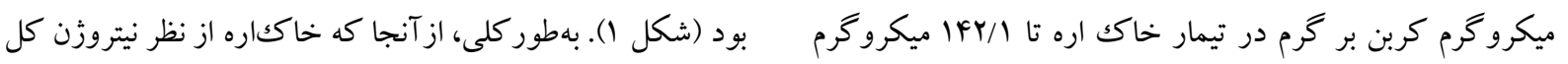


همكاران (2000) مشاهده كردند كه pH ضايعات آشيزخانه طى فرايند ورمى كميوستسازى از 9/ه به V/9 كاهش يافت.

هدايت الكتريكى (EC)

افزايش زمان انكوباسيون باعث افزايش EC در تمام تيمارها شد و EC ورمى كميوستهاى توليدشده بيشتر از ضايعات اوليه بود

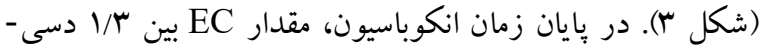

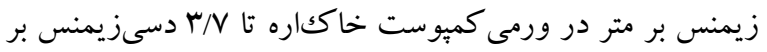
متر در ورمى كميوست خاككاره حاوى •ا درصد يودر خون متغير بود. افزايش مقدار EC بهترتيب در ورمى كميوست خاككاره حاوى •ا درصد يودر خون (qF/V درصد)، ورمى كميوست خاككاره حاوى ه درصد بودر خون (VN/ه درصد) و ورمى-

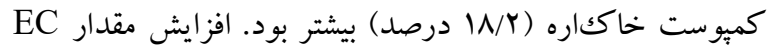
ممكن است ناشى از كاهش وزن مواد آلى و آزادسازى نمككهاى Garg et al., 2006; ) معدنى مختلف بهشكل در دسترس باشد

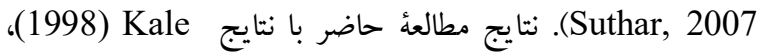
مبنى بر افزايش نمككهاى محلول و EC طى فرايند ورمىكميوستسازى، مطابقت دارد. مقدار EC تحت تأثير ظرفيت تبادل كاتيونى، تخلخل و اندازه ذرات است. تجزئه مواد آلى طى فر ايند ورمى كميوستسازى باعث كاهش اندازهُ ذرات و افزايش

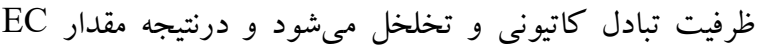
افزايش مىيابد (Grisso et al., 2009). بنابراين، افزايش جشمخير مقدار EC ورمى كميوستهاى خاككار حاوى بودر خون در مقايسه با ورمى كميوست خاككارهة، مىتواند نشاندهندة تأثير كاربرد يودرخون بر افزايش سرعت معدنى شدن خاككاره باشد. كربن آلى مقدار كربن آلى در تمام تيمارها طى فرايند ورمى كمبوست-

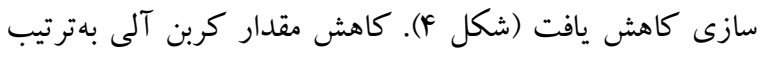

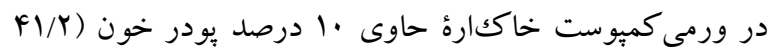

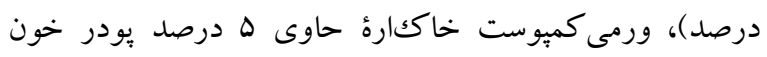

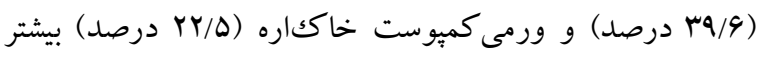
بود. در فرايند توليد ورمى كمبوست، بخش عظيمى از كربن آلى دورئ

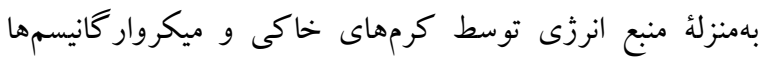

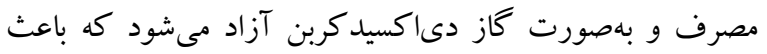

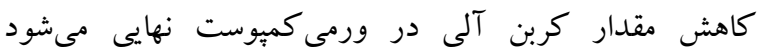
Khwairakpam \& Bhargava, 2009)
فقير است و داراى نسبت C:N زياد است (جدول ()، از كيفيت بايين تجزيهيذيرى برخوردار است؛ بنابراين، مقدار زياد دى-

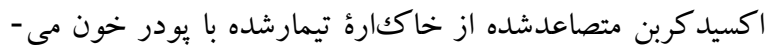
تواند مربوط به تجزيهِيذيرى بيشتر اين تركيبات ناشى از مقدار زياد

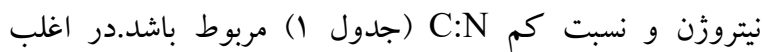

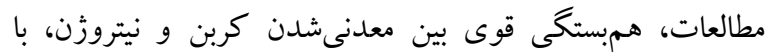
مقدار نيتروزن كل و نسبت C:N مو اد آلى، مشاهده شده است. به طورى كه تجزيه با سرعت زياد در موادى با نيتروزن زياد و كربن كم انجام مى گيرد و كمبودن مقدار نيتروزن در ساختار تركيبات Trinsoutrol et al., 2000; ) آلى، سرعت تجزيه را كند مى كنى .(Thuries et al., 2002; Sall et al., 2007 pH در هفتهاى اول انكوباسيون، pH روند افزايشى نشان داد و پِس از كذشت جهارماه از فرايند ورمى كمبوستسازى، pH در تمام pH pH بمارها بهور جزئى كاهش يافت (شكل Y). افزايش مقدار طى مراحل اولية انكوباسيون ممكن است بهعلت تجزيئ تركيبات

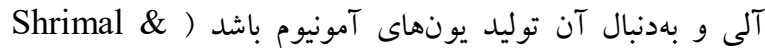
pH Khwairakpam, 2010 بين 9/9در ورمى كمبوست خاككارهٔ حاوى ·ادرصد بودر خون تا V/ه در ورمى كميوست خاككاره بدون يودر خون متغير بود. كاهش جزئى pH ورمى كميوستها در مقايسه با ضايعات آلى اوليه، ممكن است بهعلت معدنىشدن نيتروزن و فسفر، تجزئ ميكروبى مواد آلى و توليد اسيدهاى آلى حد واسط مانند اسيد

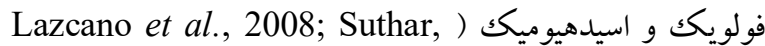
2009) و نيز توليد دىاكسيدكربن ( Elvira et al., 1998; (Garg et al., 2006 كميوستهاى مختلف ناشى از كيفيت ضايعات آلى استفادهشده در بستر كرم خاكى است، كه بر فرايند معدنى شدن و ونو نوع تركيبات

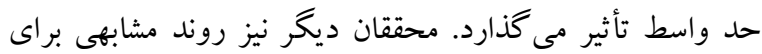
pH در ورمى كميوستهاى توليدشده از ضايعات آلى مختلف Ndegwa \& Thompson, 2000; Suthar, ) كزارش كردهاند 2009). در اين زمينه، Bisen و همكاران (2011) نشان دادند كه pH كاوى توسط كرمهاى Eisenia و Eudrilus بهطور معنىدارى كمتر از pH اولية اين تركيبات بود. همجنين، Chudhary و 


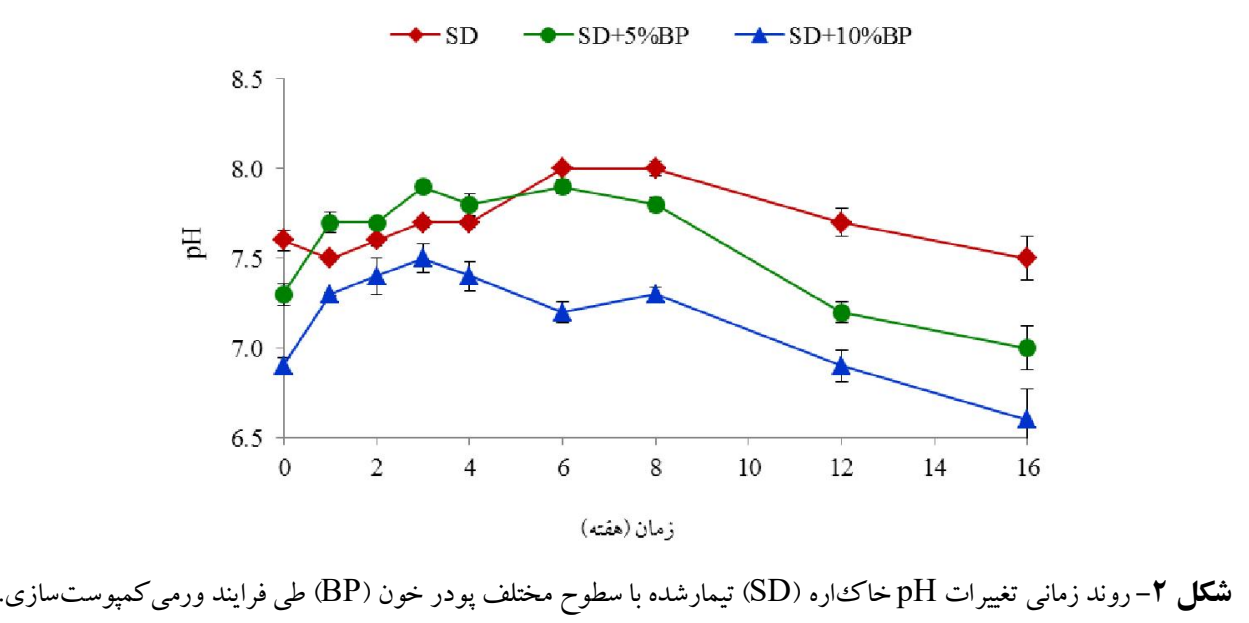

Fig. 2. Periodical change in sawdust (SD) pH treated with different levels of blood powder (BP) during vermicomposting process.

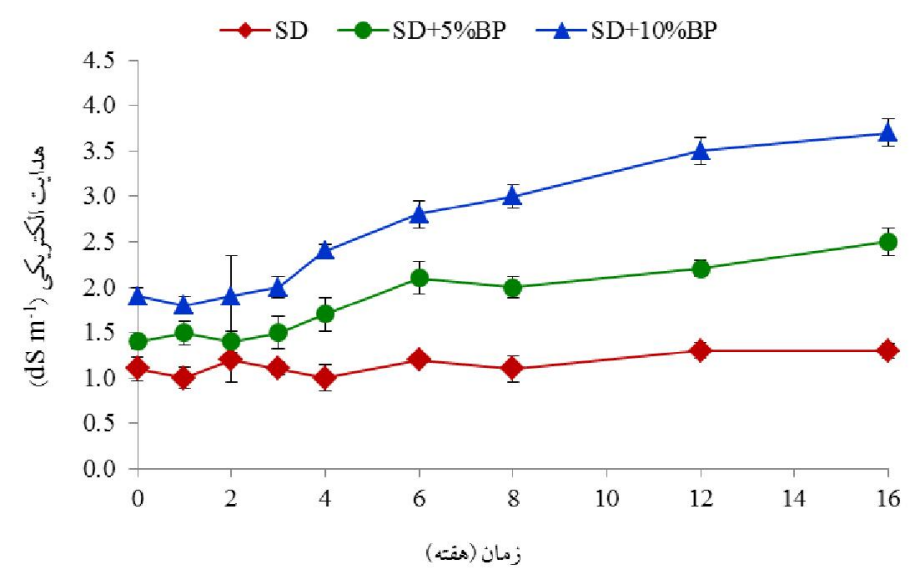

شكل r- روند زمانى تغييرات هدايت الكتريكى خاككارة (SD) تيمار شده با سطوح مختلف يودر خون (BP) طى فر ايند ورمى كميوستسازى.

Fig. 3. Periodical change in sawdust (SD) electrical conductivity treated with different levels of blood powder (BP) during vermicomposting process.

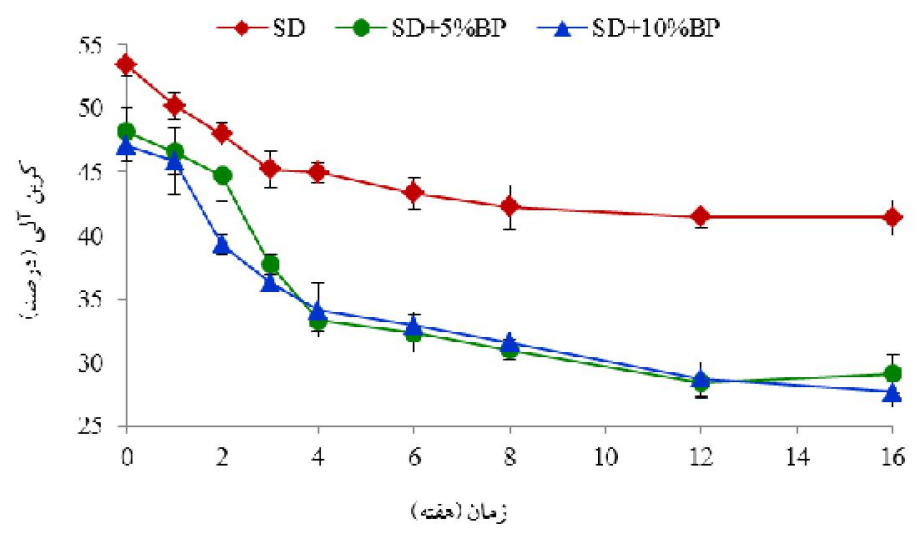

شكل ع- روند زمانى تغييرات كربن آلى خاككار (SD) تيمارشده با سطوح مختلف يودر خون (BP) طى فرايند ورمى كميو ستسازى.

Fig. 4. Periodical change in sawdust (SD) organic carbon treated with different levels of blood powder (BP) during vermicomposting process. 


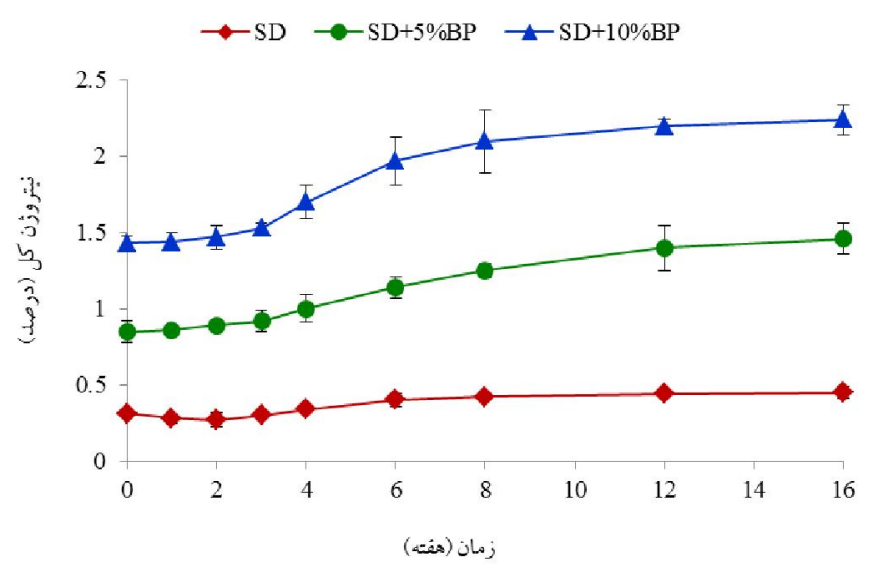

شكل 0- روند زمانى تغييرات نيتروزن كل خاككارة (SD) تيمارشده با سطوح مختلف بودر خون (BP) طى فرايند ورمى كمبوستسازى.

Fig. 5. Periodical change in sawdust (SD) total nitrogen treated with different levels of blood powder (BP) during vermicomposting process.

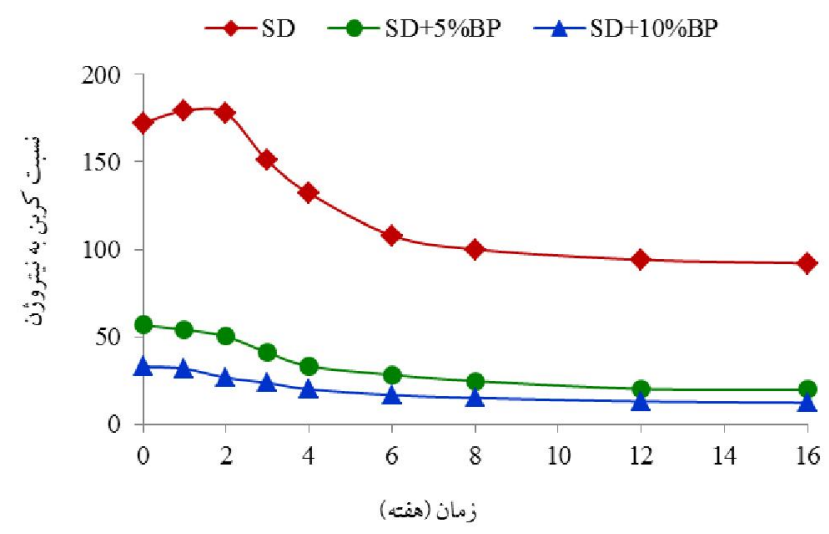

شكل 7- روند زمانى تغييرات نسبت كربن نيتروزن خاككارة (SD) تيمارشده با سطوح مختلف يودر خون (BP) طى فرايند ورمى كميوستسازى.

Fig. 6. Periodical change in sawdust (SD) carbon to nitrogen ratio treated with different levels of blood powder (BP) during vermicomposting process.

تر كيبهاى با C:N

$$
\text { درصد كاهش يافت. }
$$

نيتروزن كل

غلظت نيتروزن كل در تمام تيمارها، طى فرايند ورمى كميوست -

سازى افزايش يافت، اگرجهه مقدار اين افزايش در تيمارهاى حاوى يودر خون بيشتر بود (شكل ه). غلظت نيتروزن كل در پيايان زمان

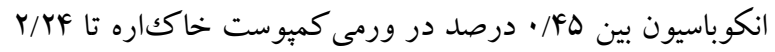
درصد در ورمى كميوست مخلوط خاككاره و ·1 درصد يودر خون متغير بود. افزايش غلظت نيتروزن بهترتيب در ورمى كميوست خاككارهٔ حاوى ه درصد بودر خون (VI/N درصد)، ورمىكميوست خاككارهٔ حاوى ·ل درصد يودر خون (ه/ه دورصد) و ورمى كميوست خاككاره (FD/Y درصد) بيشتر بود. افزايش غلظت
كربن آلى كود گاوى، لجن فاضلاب شهرى و كاه برنج طى فرايند ورمى كميوستسازى را توسط Das و همكاران (2014) نيز كزارش دادهاند. در مطالعهُ حاضر، كاهش بيشتر مقدار كربن آلى در ورمى كمبوست خاككاره حاوى ·ل درصد بودر خون (YI/T درصد) در مقايسه با تيمارهاى ديخر، ممكن است بهعلت سرعت بيشتر تنفس (Suthar, 2009) باشد. در اين زمينه، Kumar Nayak و همكاران (2013) كزارش كردند كه افزودن لجن فاضلاب به كود كاوى و خاكاره باعث كاهش بيشتر كربن آليدر فرايند ورمى كميوستسازى مىشود. همجنين، Shrimal و Khwairakpam (2010) مشاهده كردند كه يس از كذشت سF روز از فرايند توليد ورمى كميوست از مخلوط نسبتهاى مختلف ضايعات سبزيجات و كود گاوى، مقدار كربن آلى در 
مطالعهاى Tripathi و Bhardwaj (2004) گزارش كردند كه تر يبات با نسبت C:N يايين براى تغذية كرم هاى خاكى مناسبت تر هستند و باعث افزايش سرعت تجزئ مواد آلى مىشوند. همجنين، Gunadi و همكاران (2003) مشاهده كردند كه كاربرد كودهاى كاوى و خوكى با نسبتهاى C:N بايين در فرايند ورمى كميوستسازى، باعث افزايش سرعت رشد و تكثير كرم خاكى گونه E. foetida شد. در مطالعه حاضر مشاهده شد كه نسبت C:N خاككارة حاوى ها درصد يودر خون از ه9/V به 19/9

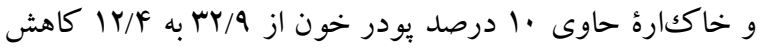
يافت. براساس نتايج Morais و Queda (2003)، كاهش نسبت C:N است و نشان مىدهد كه ضايعات آلى بهاندازه كافى تجزيه شده اند. هميجنين، در مطالعهُ حاضر مشاهده شد كه ورمى كميوستهاى تهيهشده از مخلوط خاككاره و بودر خون بس از گذشت جهار ماه، تيرهتر و يكنواخت تر بودند. اين مىتواند نشاندهندهُ تأثير مثبت يودر خون بر افزايش تجزيه خاككاره باشد. نتيجه نتايج مطالعهُ حاضر نشان داد كه بودر خون مىتواند از طريق افزايش سرعت تجزئ خاككاره طى فرايند ورمى كمبوست سازى، باعث ايجاد تغييرات زيادى در ويز كىهاى بيوشيميايى ورمى كمبوست خاككاره شود. بلطور كلى، افزايش زمان انكوباسيون در فرايند توليد ورمى كميوست، باعث افزايش مقدار تجمعى كربن معدنىشده، نيتروزن كل و EC و كاهش كربن آلى، نسبت C:N و تمام تيمارهاى ورمى كميوست در مقايسه با ضايعات اوليه شد و شدت اين تغييرات بيوشيميايى در تيمارهاى حاوى يودر خون بيشتر بود. اخرجّه با اضافه كردن بودر خون به بستر خاككاره، امكان بازيافت اين ضايعات به ورمى كميوست فراهم مىشود، قبل از كاربرد اين كودها در كشاورزى، نياز به مطالعات تكميلى در باره تأثير آنها بر ويز گیىهاى خاكك و رشد و عمل كرد كياهان وجود دارد.

\section{سياسگزارى}

از كارشناسان آزمايشگاه خاككشناسى و بيولوزى و ميكرو بيولوزى خاكك دانشگاه يزد قدردانى مىشود.
نيتروزن در فرايند و ورمى كمبوستسازى، ناشى از آزادشدن نيتروزن توسط كرمهاى خاكى بهعلت تشكيل متابوليتهاى مختلف مانند هورمونهاى محركك رشد و بافتهاى مرده است .(Tripathi \& Bhardwaj, 2004) بسيارى از مطالعات انجامشده دربارهُ فرايند ورمى كمبوست سازى، به افزايش غلظت نيتروزن در بايان زمان انكوباسيون اشاره كردهاند. در اين زمينه، AngLopez و Aarman (2002) مشاهده كردند كه بعد از خذشت هأ و \$ و روز از انكوباسيون، غلظت نيتروزن در سه نوع ضايعات ورمى كميوست شده، FY-AD درصد افزايش يافت. Suthar (2009) بيان كرد كه افزايش غلظت نيتروزن كل در ضايعات ورمى كمبوست شده، ناشى از معدنىشدن مواد آلى طى فرايند ورمى كمبوستسازى است؛ بنابراين، افزايش بيشتر غلظت نيتروزن در بسترهاى حاوى يودر خون در مطالعه حاضر، مىتواند ناشى از سرعت بيشتر معدنىشدن خاككاره باشد. اين نتايج با كاهش مقدار كربن آلى همخوانى دارد (شكل \&) \&enitez و همكاران (1999) نيز گزارش كردند توليد آنزيمهاى هيدروليتيكك كه نقش مهمى در جر خهُ كربن و نيتروزن در سيستم تجزئ ضايعات آلى دارند، بسيار تحت تأثير قابليت دسترسى تركيبات آلى تجزيهٍٍير در بستر كرم خاكى است.

(C:N) نسبت كربن به نيتروزن

طى فرايند ورمى كميوست سازى، تغييرات جشمخيرى در نسبت C:N با كذشت زمان كاهش يافت. در پيايان زمان انكوباسيون، نسبت C:N بين C:N/ يودر خون تا بو/ • در ورمى كميوست خاككاره متغير بود. درواقع، افزايش غلظت نيتروزن ناشى از تركيبات نيتروزنه توليدشده توسط كرمهاى خاكى و همجنين تلفات كربن آلى بهصورت دى C:N اكسيدكربن ناشى از فعاليت ميكروبى، باعث كاهش نسبت ورمى كميوست هاى نهايى مىشود. در مطالعات متعدد به كاهش نسبت C:N طى فرايند ورمى كميوستسازى اشاره شده است (Bansal \& Kapoor, 2000; Gupta \& Garg, 2008) مطالعهُ حاضر، كاربرد بودر خون باعث تسريع در كاهش نسبت C:N ورمى كميوست خاككاره شد كه اين امر مبين سرعت بيشتر تجزيه و معدنىشدن مواد آلى است. نسبت C:N شاخصى از درجة تجزية مواد آلى شناخته مىشود (Atiyeh et al., 2000). در 


\section{REFERENCES}

Abd El Halim, A.A. and El Baroudy, A.A. 2014. Influence addition of fine sawdust on the physical properties of expansive soil in the Middle Nile Delta, Egypt. - J. Soil Sci. Plant Nutr. 14: 483-490.

Aira, M., Monroy, F. and Domínguez, J. 2006. C to N ratio strongly affects population structure of Eisenia foetida in vermicomposting systems. - Eur. J. Soil Biol. 42: 127-131.

Alexander, M. 1999. Biodegradation and Bioremediation. $2^{\text {th }}$ ed. - Academic Press, NY.

Atiyeh, R.M., Subler, S., Edwards, C.A., Bachman, G., Metzger, J.D. and Shuster, W. 2000. Effects of vermicomposts and composts on plant growth in horticulture container media and soil. - Pedobiologia 44: 579-590.

Bansal, S. and Kapoor, K.K. 2000. Vermicomposting of crop residues and cattle dung with Eisenia foetida. Bioresource Technol. 73: 95-98.

Benitez, E., Nogales, R., Elvira, C., Masciandaro, G. and Ceccanti, B. 1999. Enzyme activities as indicators of the stabilization of sewage sludge composting with Eisenia foetida. - Bioresource Technol. 67: 297-303.

Bisen, J.S. Singh, A.K. Kumar, R. Bora, D.K. and Bera, B. 2011. Vermicompost quality as influenced by different species of earthworm bedding material. Two Bud. 58: 137-140.

Bremmer, J.M. and Mulvancey, C.S. 1982. Total nitrogen. In: Page, A.L., Miller, R.H. and Keeney, D.R. (eds.), Method of soil analysis. 2: 599-622. Aragon Monogr, 9, ASA and SSSA, Madison, WI.

Chudhary, P.S., Pal, T.K., Bhattachrjee, G. and Dey, S.K. 2000. Chemical characterization of kitchen waste vermicompost processed by Perionyx excavatus. - Environ. Ecol. 18: 902-904.

Das, D., Powell, M., Bhattacharyya, P. and Banik, P. 20014. Changes of carbon, nitrogen, phosphorous, and potassium content during storage of vermicomposts prepared from different substrates. Environ. Monit. Assess. 186: 8827-8832.

Elvira, C., Sampedro, L., Benítez, E. and Nogales, R. 1998. Vermicomposting of sludges from paper mill and dairy industries with Eisenia andrei: a pilot-scale study. - Bioresource Technol. 63: 205-211.

Garg, P., Gupta, A. and Staya, S. 2006. Vermicomposting of different types of waste using Eisenia foetida: A comparative study. - Bioresource Technol. 97: 391-395.

Grisso, R., Aller, M., Holshouser, D. and Thomason, W. 2009. Precision farming tools: soil electrical conductivity. - Virginia Cooperative Extension Publication, pp 442-508.

Gunadi, B., Edwards, C.A. and Blount, C. 2003. The influence of different moisture levels on the growth, fecundity and survival of Eisenia foetida (Savigny) in cattle and pig manure solids. - Eur. J. Soil Biol. 39:19-24.

Gupta, R. and Garg, V.K. 2008. Stabilization of primary sewage sludge during vermicomposting. - J. Hazard. Mater. 153: 1023-1030.
Hesse, P.R. 1971. A Text Book of Soil Chemical Analysis. - John Murray, London.

Kale, R.D. 1998. Earthworms: nature's gift for utilization of organic wastes. In: Edwards C.A. (ed.), Earthworm Ecology pp: 355-376. - CRC Press, Boca Raton, Fla.

Khwairakpam, M. and Bhargava, R. 2009. Vermitechnology for sewage sludge recycling. - J. Hazard. Mater. 161: 948-954.

Kosheleva, Y.P. and Trofimov S.Y. 2008. Characteristics of the biochemical composition of plant litter at different stages of decomposition (According to thermal analysis data). - Biol. Bull. 35: 64-69.

Kumar, D.S., Kumar, P.S., Kumar, V.U. and Anbuganapathi, G. 2013. Impact of biofertilizers on growth and reproductive performance of Eisenia feti$d a$ (Savigny 1926) during flower waste vermicomposting process. - Annu. Rev Res. Biol. 3: 574-583.

Kumar, N.A., Sudharsan Varm, V. and Kalamdhad, A.S. 2013. Effect of various $\mathrm{C} / \mathrm{N}$ ratios during vermicomposting of sewage sludge using Eisenia foetida. - J. Environ. Sci. Technol. 6: 63-78.

Lazcano, C., Gómez-Brandón, M. and Domínguez, J. 2008. Comparison of the effectiveness of composting and vermicomposting for the biological stabilization of cattle manure. - Chemosphere 72: 1013-1019.

Morais, F.M.C. and Queda, C.A.C. 2003. Study of storage influence on evolution of stability and maturity properties of MSW composts. In: Proceeding of the fourth International Conference of ORBIT association on Biological Processing of Organics: Advances for a Sustainable Society part II. Perth, Australia.

Nagavallemma, K.P., Wani, S.P. and Stephane, L. 2006. Vermicomposting: recycling wastes into valuable organic fertilizer. - J. Sat Agr. Res. 2: 1-17.

Ndegwa, P.M. and Thompson, S.A. 2000. Effects of Cto-N ratio on vermicomposting of biosolids. - Bioresource Technol. 75: 7-12.

Nelson, D.W. and Sommers, L.P. 1986. Total carbon, organic carbon and organic matter. In: Page, A.L. (ed.), Method of soil analysis. 2: 539-579. - Am. Soc. Agron. Madison. WI. USA.

Ray, M.R., Roychoudhury, S., Mukherjee, G., Roy, S. and Lahiri, T. 2005. Respiratory and general health impairments of workers employed in a municipal solid waste disposal at open landfill site in Delhi. Int. J. Hyg. Envir. Heal. 108: 255-262.

Sall, S., Bertrand, I., Chotte J.L. and Recous, S. 2007. Separate effects of the biochemical quality and $\mathrm{N}$ content of crop residues on $\mathrm{C}$ and $\mathrm{N}$ dynamics in soil. - Biol. Fert. Soils 43: 797-804.

Sharholy, M., Ahmad, K., Mahmood, G. and Trivedi, R.C. 2008. Municipal solid waste management in Indian cities: A review. - Waste Manage. 28: 459467.

Shrimal, S. and Khwairakpam, M. 2010. Effect of C/N ratio on vermicomposting of vegetable waste. - Dyn. Soil Dyn. Plant. 4: 123-126.

Suthar, S. 2007. Vermicomposting potential of Perionyx sansibaricus (Perrier) in different waste materials. Bioresource Technol. 98: 1231-1237. 
Suthar, S. 2009. Vermicomposting of vegetable-market solid waste using Eisenia foetida: Impact of bulking material on earthworm growth and decomposition rate. - Ecol. Eng. 35: 914-920.

Thuries, L., Pansu, M., Larre-Larrouy, M.C. and Feler, C. 2002. Biochemical composition and mineralization kinetics of organic inputs in a sandy soil. - Soil Biol. Biochemi. 34: 239-250.

Tiunov, A.V. and Scheu, S. 2004. Carbon availability control the growth of detritivores (Lumbricidae) and their effect on nitrogen mineralization. - Oecologia 138: 83-90.

Trinsoutrol, I., Recouse, S., Bents, B., Lineres, M., Cheneby D. and Nicolardot, B. 2000. Biochemical quality of crop residues and carbon and nitrogen mineralization kinetics under nonlimiting nitrogen condition. - Soil Sci. Soc. Am. J. 64: 918-926.

Tripathi, G. and Bhardwaj, P. 2004. Comparative studies on biomass production life cycles and composting efficiency of Eisenia foetida (Savigny) and Lampito mauritii (Kinberg). - Bioresource Technol. 92: 275-283.

Warman, P.R. and Anglopez, M.J. 2002. The chemical properties of vermicompost derived from different feed stocks, proceeding of international composting and compost science symposium, Columbus, Ohio. 68 June.

Zziwa, A., Kizito, S., Banana, A.Y., Kaboggoza, J.R.S., Kambugu, R.K. and Sseremba, O.E. 2006. Production of composite bricks from sawdust using portland cement as a binder. - Uganda J. Agri. Sci. 12: 3844.

\section{How to cite this article:}

Ghasemi, S. 2018. The effect of blood powder application on some biochemical properties of sawdust during vermicomposting. - Nova Biologica Rep. 4: 310-319.

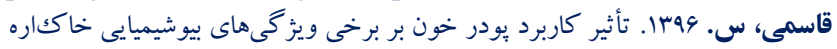

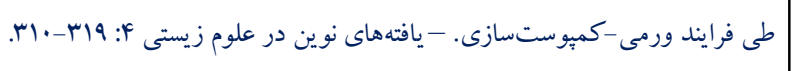

